ISSN: 2162-3104 Print/ ISSN: 2166-3750

Online Volume 8, Issue 4 (2018), pp. 1879-1890

(C) Journal of International Students

http://jistudents.org/

doi: $10.5281 /$ zenodo. 1471736

\title{
Writing Gravity: International Female Graduate Students' Academic Writing Experiences
}

\author{
Abir Aly Eldaba \\ Tennessee Technological University, USA \\ Janet Kesterson Isbell \\ Tennesse Technologial University, USA
}

\begin{abstract}
In a critical study, researchers explored academic writing experiences of three international female graduate students at a southern U.S. university in order to understand their perspectives of themselves as writers across cultures, their experiences with academic writing, and their coping strategies for academic writing assignments. Findings revealed participants' challenges and self-doubts about second-language writing abilities. Participants both challenged disconfirmation of their writing and at times were submissive as they negotiated a graduate degree program. The study demonstrates need for universities to recognize marginalized groups' knowledge and ways of knowing and to create spaces to discuss new possibilities for academic writing experiences among international students.
\end{abstract}

Keywords: English as a second language, international students, academic writing

International students represent a growing and sizeable proportion of U.S. college students (Institute of International Education, 2017). The numbers of international students in U.S. colleges and universities climbed to 1,078,022 in the 2016-2017 academic year, an increase of $3.4 \%$ over the previous year (Institute of International Education, 2017). In 2016 alone, international students contributed $\$ 39$ billion to the U.S. economy (Institute of International Education, 2017). However, while international students' money has been a boon for higher education institutions, many universities lack sufficient programs and services to meet these students' social and academic needs (Fass-Holmes \& Vaughn, 2014). Among those academic needs is the ability to write proficiently in English, a challenge for many international students (Alsahafi \& Shin, 2017; Angelova \& Riazantseva, 1999; Kuo, 2011; Riazantseva, 2012; Spack, 1997; Whitley \& Grous, 2009). As one university administrator stated, "We recognize that people from other countries often speak with an accent. ... We have to recognize that they may write 
with an accent as well" (as cited in Lewin, 2012, para 14). The observation points to the need for international students to gain competency not only in speaking English but also in writing English.

This paper explores the academic writing experiences of three second-language international female graduate students at a southern regional U.S. university where total international student enrollment increased from 7.5\% in Fall 2012 to 9\% in Fall 2015. The university offers various services and programs to assist international students, yet faculty and advisors in graduate programs have expressed concerns that international students struggle with academic writing. Using a critical case study approach, the researchers conducted in-depth interviews in order to understand the international graduate students' thinking about themselves as writers, their challenges with academic writing, and their coping strategies for academic writing assignments.

Questions addressed included:

- What are international female graduate students' perspectives about themselves as writers across cultures?

- What are international female graduate students' experiences with writing assignments for their classes at a U.S. university?

- How do female international students negotiate academic writing challenges at a U.S. university?

\section{LITERATURE REVIEW}

Our review of research into the experiences, perspectives, and interactions of international students studying in the United States and at other English-language universities was focused on findings related to writing challenges, coping strategies for writing challenges, and writing feedback.

Among factors contributing to writing challenges cited in the research were differences between first- and second-language writing styles (Abasi \& Graves, 2008; Alsahafi \& Shin, 2017; Angelova \& Riazantseva, 1999; Baird \& Dooey, 2014; Bauer \& Picciotto, 2013; Ravichandran, Kretovics, Kirby, \& Ghosh, 2017; Shang-Butler, 2015; Wang \& Li, 2008; Whitley \& Grous, 2009). The differences included different cultural norms about critiquing authority (Abasi \& Graves, 2008; Angelova \& Riazantseva, 1999; Wang \& Li, 2008; Whitley \& Grous, 2009; Zghyer, 2014) as well as the need for more explanation of assignments due to lack of familiarity with English writing tasks and terms (Bauer \& Picciotto, 2013). A study of 100 students from Saudi Arabia studying in Australian universities found the most significant language difficulties involved written tasks and classroom discussion (Alsahafi \& Shin, 2017). In a survey of $40 \mathrm{Arab}$ participants studying in the United States, including 17 from Saudi Arabia, students indicated their educational background, different learning experiences, and lack of preparation in their home countries contributed to writing difficulties (Zghyer, 2014). Chinese students studying in Upstate New York found U.S. critical thinking skills to be significantly different from the way they were taught writing in their first language (Shang-Butler, 2015). Additional factors identified in the literature as contributing to writing difficulties for international students were emotional barriers about interacting with professors (Angelova \& Riazantseva, 1999), professors' failure to become acquainted with international students' backgrounds and culture (Angelova \& Riazantseva, 1999), lack of confidence in writing skills (Weaver \& Jackson, 2011), and inadequate writing skills despite good speaking skills (Wang \& Li, 2008). Students experienced writing difficulties even after participating in ESL classes (Leki \& Carson, 1997; 
Spack, 1997), which lacked preparation for academic writing. Baird and Dooey (2014) found that students' deficits in language skills meant they had trouble comprehending course guidelines and evaluations.

International students in the reviewed studies identified various coping strategies in their quest for academic distinction in English-speaking universities. Some students described completing writing assignments in their first language, then translating the writing into English (Angelova \& Riazantseva, 1999). Other coping strategies included self-motivation (Angelova \& Riazantseva, 1999) and peer assistance (Angelova \& Riazantseva, 1999; Leki, 1995; Ravichandran et al., 2017; Shang-Butler, 2015; Wang \& Li, 2008). Studies found that international students sought communication with professors (Leki, 1995; Wang \& Li, 2008) and used professors' feedback (Leki, 1995; Weaver \& Jackson, 2011). Reading also was a coping strategy (Leki, 1995; Wang \& Li, 2008), including reading aloud (Wang \& Li, 2008) and searching for good writing models (Leki, 1995). International students studying in English at a university in Malaysia enrolled in writing courses (Singh, 2015).

Participants in a survey of 65 Saudi Arabian students studying in New Zealand found that most sought writing and proofreading help from university centers (Ankawi, 2105), and some participants also used private tutors. Participants in Wang and Li's 2008 study identified accessing writing centers and writing workshops as coping strategies, but Whitley and Grous (2009) found that students did not use writing centers or tutors. Bauer and Picciotto (2013) found that tutors mostly explained course requirements instead of assisting with writing skills, and Wang (2012), studying 16 students and 16 tutors at two eastern U.S. universities, found that tutors used the same practices for both international and U.S. students, overlooking the differences in students' needs. Ravichandran et al. (2017) found that writing center help was mostly limited to corrections of spelling and grammar. Wang learned that tutors felt neither confident in their abilities to tutor international students nor responsible for helping them. Moussu (2013) noted the conflict between international students' expectations and tutors' ways of teaching.

International students valued professors' feedback on writing assignments (Leki, 1995; Leng, 2014; Ravichandran et al., 2017; Seror, 2009; Weaver \& Jackson, 2011). In an eight-month study, Seror (2009) found that international students valued written feedback that led to conversation with instructors and in turn improved writing skills, but participants complained of minimal feedback that lacked advice on how to improve writing. Bitchener et al. (2005) found that both written and conversational feedback helped students with grammatical issues but failed to improve writing in general. Both Leng (2014) and Shang-Butler (2015) found that international students preferred specific direction on explicit changes rather than comments that relayed instructors' feelings about student writing (Leng, 2014) or offered only encouraging expressions (Shang-Butler, 2015).

Most international students are required to demonstrate language competency before enrolling in U.S. universities, yet research has demonstrated that passing scores on English proficiency exams do not guarantee students' success at universities, where writing is frequently required in assignments, particularly in graduate coursework. Using qualitative research methods, Wan (1999) explored cross-cultural learning experiences of a graduate Chinese student and his wife at an eastern university. The participants stated that achieving a passing score on a standardized test of English proficiency, such as the Test of English as a Foreign Language (TOEFL), required for admission to many universities, did not mean students were adequately prepared for academic work in English. This finding was consistent with Trice (2003), whose 
participants - faculty from a Midwest U.S. university - demonstrated that TOEFL scores did not reflect English language competence.

Clearly, international students studying at U.S. or other English-speaking universities struggle with English-only writing assignments, and many have developed coping strategiessome more successfully than others - as they seek to advance their education. Our continued quest to understand the nature of writing difficulties from the international student's perspective is important for English-language academic communities that find increasing numbers of international students in their classrooms.

\section{RESEARCH METHOD}

The researchers used critical theory to explore international students' writing experiences. Giroux (1983) called for the use of critical theory to investigate schooling and the ways that "knowledge and meanings of subordinate groups are experienced and interpreted" (p. 68). In this study, international female graduate students were marginalized in an academic setting due to their language and cultural differences. Researchers explored their academic writing experiences, including their perspectives on the adequacy of the university to address their academic needs. According to Giroux (1983), educators who frame their work within critical theory focus on "breaks, discontinuities, and tensions in history" (p. 36) in order to learn how people act and respond in those instances; in focusing on those actions, critical theorists aim to reveal "the gap between society as it presently exists and society as it might be" (p. 36). Giroux argued for using ideology to look within and question assumptions behind teaching practices that may stifle learning, especially "for those students who experience daily the pain of humiliation and powerlessness because their own lived experiences and sedimented histories are at odds with the dominant school culture" (p. 68). Studying international female graduate students as they encounter academic writing practices at a U.S. university and calling attention to their struggles and challenges may lead to the university's appraisal of its own policies and practices directed toward key stakeholders. Considering the growth in recent years and size of international student enrollments, universities should maintain policies and procedures that help international students develop knowledge of expectations within the U.S. academic environment, including writing skills required for success, but also should discourage policies that marginalize and limit academic achievement of internationals. As Albertinti (2010) noted, "The development of independence, confidence, and a sense of agency is as important for second-language writers as native speakers" (p. 391).

\section{Setting}

The study was conducted in Fall 2014 at a regional university in the Southeast United States. The university is set in a mostly Protestant and conservative city of 31,000 that, according to the city's website, attracts some 15,000 commuters from surrounding rural communities for employment, education, and health care. In 2014, the university's student body of 11,000 was predominantly white and from immediate and neighboring counties but included 960 international students. To meet their needs, the university partnered with a private agency that operated ESL programs on campus and waived TOEFL test requirements for students who succeeded in the ESL programs. The university also offered tutoring and a writing center for international students. 


\section{Participants}

Three participants, two from Saudi Arabia and one from Iran, were purposefully selected through homogeneous sampling from among international female graduate students enrolled at the university (Table 1).

Table 1: Characteristics of International Female Graduate Students

\begin{tabular}{cccccc}
\hline Participant & Age & $\begin{array}{c}\text { Home country } \\
(\text { HC) }\end{array}$ & $\begin{array}{c}\text { Degree earned in } \\
\text { HC }\end{array}$ & $\begin{array}{c}\text { U.S. academic } \\
\text { standing }\end{array}$ & $\begin{array}{c}\text { ESL learning } \\
\text { experience }\end{array}$ \\
\hline Rasha & 25 & Saudi Arabia & $\begin{array}{c}\text { Bachelor (B.S.), } \\
\text { chemistry }\end{array}$ & $\begin{array}{c}\text { Master's } \\
\text { (M.A.), } \\
\text { curriculum \& } \\
\text { instruction } \\
\text { (C\&I) }\end{array}$ & $\begin{array}{c}\text { 14 months at a } \\
\text { U.S. ESL } \\
\text { institution }\end{array}$ \\
\hline Sally & 27 & Iran & B.S., petroleum & $\begin{array}{c}\text { M.A., } \\
\text { engineering } \\
\text { engineering }\end{array}$ & $\begin{array}{c}\text { Several years } \\
\text { during middle } \\
\text { and high school } \\
\text { in Iran }\end{array}$ \\
\hline Leena & 26 & Saudi Arabia & B.S., accounting & M.A., C\&I & $\begin{array}{c}\text { 10 months at a } \\
\text { U.S. ESL } \\
\text { institution }\end{array}$ \\
\hline
\end{tabular}

The study aimed to describe the selected participants' academic writing experiences. In addition to being international graduate students, the women chosen for the study had taken ESL classes prior to enrollment in university courses. Graduate students were chosen because graduate course work often requires significant writing. Since the researchers were both female, they believed international females would be more approachable and open to participation. Participant names are pseudonyms.

\section{Data Collection}

The researchers used in-depth interviews and analysis of graded assignments to explore international students' academic writing. After securing approval from the university's Institutional Review Board for the Protection of Human Subjects, and being mindful of ethical standards (Glesne, 2006), including informed consent, the researchers arranged for a one- to twohour interview with each participant. All interviews were audio recorded and transcribed to ensure accuracy and provide verbatim data. Participants were prompted to reflect on their memories during early school and college years and on current writing experiences, and they were asked to share samples of their graded academic writing. Trustworthiness was established by use of ethical standards for research, multiple sources of data, verbatim data, researcher reflexivity, peer review, and investigator triangulation.

\section{Data Analysis}

Data were analyzed using inductive analysis, reducing data to a manageable form that enabled researchers to organize and summarize data and to assign "meaning and significance to the patterns, themes, and connections" (LeCompte \& Schensul, 1999, p. 5) discovered during 
multiple readings of transcripts. After coding of verbatim transcripts, codes and corresponding line numbers in the transcripts were entered into a word processor, then categorized to learn how codes were similar and different. The researchers used an Excel spreadsheet, naming categories and subcategories for codes, then importing coded text to the assigned categories. The researchers also looked for key or recurring events or ideas, eventually settling on the categories of personal characteristics, attitudes toward writing (involving native language and English language as subcategories), and experiences and perspectives of the language school. Finally, each category was defined. The researchers also examined instructors' feedback on students' papers.

\section{Role of the Authors}

The first author's background includes work as a pre-service English as a Second Language (ESL) teacher in her home country, Egypt, and study as a non-native English graduate student in the United States. In an attempt to be cognizant of her own role in the research, she made note of her own assumptions about ESL program policies and strategies in the university as well as her experiences as a graduate student attempting to improve her own writing skills. The second author's work with graduate students, including the first author and other international students, has led to a shift in her thinking, from one who expected international graduate students to be prepared to read and write on the same level as their U.S. peers, to one who has empathy with international students for their significant struggles and considerable accomplishments as learners in multiple languages and cultures.

\section{RESULTS}

When participant Sally put words to paper in her first language, she considered herself an accomplished Persian writer of novels and poetry. She spoke exuberantly of reading and writing in her first language. "Literature and philosophy is my love. It makes my mind fresh . . . Novels make your spirit strong." But when she crossed the Atlantic and began graduate studies in another language and culture, Sally had adverse experiences with language that caused her anxiety and assigned her a new, unwelcome writing identity. "I love writing in my language because this is in my character," she explained. "It shouldn't change when I change my language. I should continue writing, but I don't know how to transfer this ability from Persian to English. God help me."

Rasha shared a similar juxtaposition of feelings about writing in first and second languages. Writing in her first language came naturally, she said. "This isn't something you are forced to learn." But writing in a second language in a U.S. graduate school was different. Despite efforts to bolster her English by listening to YouTube videos, reading English textbooks, and writing her diary in English, Rasha was a disoriented and anxious English writer.

While Sally and Rasha both spoke confidently and positively about their first-language writing experiences, Leena said she did not enjoy writing even in her first language; she just wrote what was required to complete school assignments. Concerning second language writing, she felt "nervous and worried" about her ability to succeed.

Clearly the identities of these participants as writers across cultures were shaped by negative experiences. English-language writing experiences, part of the molding of new identities as writers across cultures, ranged from disappointing ESL preparatory courses to pressures to perform on the same level as first-language learners in graduate school. But although they at times were passive in the midst of an academic environment that was both strange and challenging, these international graduate students used coping strategies and other supports, 
enacting agency in order to create a space in which to become scholars and writers in a new language and culture.

\section{Ineffective Preparation for University Writing}

Before enrolling in a U.S. university, participants had negative experiences with training designed to teach English as a second language. Although writing is a key component of graduate studies at U.S. universities, writing was a limited part of participants' ESL training experiences. This finding was similar to findings in other studies (Leki \& Carson, 1994; Spack, 1997; Kuo, 2011) that have questioned the adequacy of English proficiency exams, such as TOEFL, and ESL programs to prepare international students for study at English-speaking universities.

Rasha and Leena both studied at the same university-affiliated ESL school where they were required to show mastery of a nine-level program of study and earn admission to the U.S. university. Both successfully finished training and bypassed the required English proficiency test, yet neither felt prepared for college-level academic writing in English. They described program courses and teaching as ineffective, with minimal attention to writing. Rasha said she reached the eighth level of the course before learning about summarizing and citing sources, and at the ninth and final level students critiqued movies. Leena said the ESL program's ineffectiveness was reflected in her pre- and post-program scores. Before coming to the United States, she studied English for two years in Saudi Arabia, and before enrolling in the U.S. ESL school, she scored 5 on the International English Language Testing System (IELTS), a test of English language proficiency. When she took the test a second time after studying in the ESL school, her score dropped to 4.

Sally studied ESL during her undergraduate years in Iran, but teachers provided little instruction in writing. "They focused on listening and speaking and grammar. My problem in English is more in writing," she said. When she enrolled at a U.S. university, she inquired about a writing course that might help prepare her for the academic tasks ahead. "They told me that my TOEFL grade is good" and there was no writing class for international students who scored well on TOEFL. But preparing for an ESL test, she said, was different from the type of academic writing that was required in graduate coursework.

Despite inadequate preparation, the three participants met the requirements for admission: Rasha and Leena completed the required English language training, and Sally earned a passing score on the TOEFL exam. All three then began graduate coursework.

\section{Writing Under Pressure}

In describing their experiences with academic writing in English, participants all spoke of anxiety and of doubting their academic abilities. Interviewed separately, each used the same word multiple times to describe the writing task: "hard." Their feelings of inadequacy were magnified by perceptions that English-speaking peers approached the same tasks with relative ease and speed. These findings further confirmed what other research (Abasi \& Graves, 2008; Angelova \& Riazantseva, 1999; Bauer \& Picciotto, 2013; Shang-Butler, 2015; Wang \& Li, 2008; Whitley \& Grous, 2009) has described - the extent and nature of difficulties of academic writing tasks for second-language learners at English-speaking universities.

Before registering for a class, Rasha asked her peers how much writing was required so that she could begin to prepare herself for the task ahead. She recalled that her professor once asked her to write on a chosen topic-why she chose it, how it was related to the course curriculum, and how it was related to her future goals. "So how can I write this"? she recalled asking herself. "I take my kid and put him on the television, just give him a snack, 'Leave me alone' .. . This will be fighting to write." For Rasha, writing was so challenging she considered it a "fighting" task. 
Writing assignments also triggered anxiety for Sally. She doubted her own abilities, which led to procrastination:

"I just panic because How to start? How should I end it? What should I do? If it's my own language, that is easier. I should read it, then I can write about it . . . So I just panic."

One ongoing source of anxiety was a looming graduation requirement to publish a journal article. She said repeatedly, "I'm not good at writing English . . It's hard." Unlike her U.S. peers, she needed considerable time to complete the task: "I should read, then write and change a lot of things: the words, the subject and the verb, and this kind of things. They're fast because it's their own language."

Like Sally, Leena approached writing with nervousness, worry, and fears. "I'm afraid that I don't write good and afraid that my writing will be weak and not having good expressions." Leena also noted that she spent more time on writing assignments than her peers. "I feel that I will do a lot of work and need more time to do it, and work hard and go to the writing center many time [to] finish writing." During one class, a professor asked her to accept an incomplete because of her writing inadequacies. Leena surmised: "She doesn't like my way of writing because I'm international . . She doesn't understand what I write." Her sense that a professor was uninterested in supporting her corresponded with other research (Angelova \& Riazantseva, 1999) that pointed to the disconnect between professors and international students.

Participants had different ideas about preferred academic writing assignments but similar thoughts about which type of writing was most difficult. Rasha preferred writing summaries, while Leena preferred opinion pieces. "It's easy to say my opinion, but summary-I don't know what to say about each paragraph," she explained. Critique was the least desirable type of writing assignment for participants, which aligned with the findings of previous studies (Abasi \& Graves, 2008; Angelova \& Riazantseva, 1999; Wang \& Li, 2008; Whitley \& Grous, 2009). Rasha said criticizing authority was unacceptable in her culture. "I can't critique someone who is more professional than me," she explained. Leena, however, expressed a different reason for difficulties with critiquing the works of other scholars: "It is hard . . . I don't have the power to critique them because of my language."

\section{Coping Strategies}

Their English writing skills might have been limited, but participants were determined to earn graduate degrees from the U.S. university; thus, in ways similar to those documented by other researchers (Angelova \& Riazantseva, 1999; Leki, 1995; Shang-Butler, 2015; Singh, 2015; Wang \& Li, 2008), the participants developed coping strategies, sought information and assistance, and discovered perils to be avoided.

Rasha and Leena prepared for writing by searching for a model to follow. When they did not have the background knowledge to write on a topic, they searched Google for information to increase their understanding. Sally also read relevant literature. Once they began work on their papers, Rasha and Leena said, they relied on assistance from the campus writing center and also sought help from peers whose first language was English. Both said peer reviewers were more useful than writing center tutors, who often were unfamiliar with the research process and citation styles. Other researchers also have reported the disconnect between international students' needs and writing centers (Bauer \& Picciotto, 2013; Moussu, 2013; Wang, 2012; Whitley \& Grous, 2009). Peer support also was sought by participants in earlier studies (Angelova \& Riazantseva, 1999; Leki, 1995; Shang-Butler, 2015; Wang \& Li, 2008). 
Participants shared the opinion that feedback from professors was essential to success, and they insisted that professors provide detailed, readable, and constructive feedback. "If there is something wrong, they have to explain to me and write for me," Leena said. "Sometimes the comments - I don't understand it . . . so I have to go to them and understand," Leena said. Rasha appreciated a professor who offered to edit her assignment before submission and met her to explain feedback, which included comments on citation and redundancy as well as on grammar and mechanics of writing. These findings align with earlier studies that demonstrated international students both desired and used professors' feedback (Leki, 1995; Wang \& Li, 2008; Weaver \& Jackson, 2011). An essential supporter for Sally was her advisor, who edited drafts of an article intended for publication, providing feedback on structure and ideas as well as on grammar and punctuation. Sally noted that she did not agree with all her advisor's feedback; nevertheless, she usually applied the suggestions without challenge.

\section{Avoiding Pitfalls}

In addition to developing coping strategies and seeking support, participants learned ways to avoid the perils of academic writing in a second language, particularly errors that might lead to academic misconduct. Their efforts were not always successful.

Each participant said she worked diligently to avoid plagiarism and to properly cite sources in academic papers. Leena reported spending a long time trying to pass an online plagiarism quiz, and both Leena and Rasha indicated they understood the importance of avoiding plagiarism. Yet feedback on Rasha's and Leena's work flagged citation errors, sometimes multiple times. Sally indicated more confidence in her citation abilities but said she spent considerable time, as did participants in another study (Abasi \& Graves, 2008), on ensuring citation accuracy.

One opinion shared by participants was the need to avoid writing in their first language, then translating into English, which has been identified elsewhere in research as a coping strategy (Angelova \& Riazantseva, 1999). Participants said the strategy delays mastery of English. "You should adapt to this language," Sally said. "If you go back to your language, it's hard to adapt to the new language." She added that she takes few notes in her first language. Rasha and Leena also said they limited use of internet translators because structural differences between languages made translation problematic.

\section{DISCUSSION AND CONCLUSIONS}

In describing the challenges of international graduate students' academic writing at a U.S. university, this study aligns with a body of research that demonstrated international students accepted into U.S. universities often were unprepared for academic writing challenges (Angelova \& Riazantseva, 1999; Baird \& Dooey, 2014; Kuo, 2011; Weaver \& Jackson, 2011) and endured hardship in their efforts to succeed. Furthermore, the study confirms earlier research (Kuo, 2011; Trice, 2003; Wan, 1999) that indicated international students' TOEFL and ESL training were inadequate measures of their abilities to succeed in U.S. university classrooms. Despite successfully completing such programs, participants in this study endured anxiety and stress brought on by academic writing challenges that left them doubting their own abilities to succeed. Even when they thought of themselves as competent writers in their first language, participants lost that confidence when they began writing in a second language at a U.S. university. Their experiences illustrate "the pain and humiliation of powerlessness" (Giroux, 1983, p. 68) as their knowledge and way of knowing become inferior to the U.S. way of schooling, and such experiences are where "immanent critique of the dominant society may be found" (p. 68). 
We find troubling that despite years of research that produced findings similar to those of our own, international graduate students continue to suffer anxiety and fear that extends beyond the classroom as they attempt to meet the writing demands of coursework at U.S. universities. In the words of participants in this study, admission standards, English-language training programs, and writing centers have not met the needs of these students, and at times those needs have been discounted or overlooked. As Giroux notes, the dominant culture uses "pedagogy and ideology that disconfirms the traditions and lived experiences of the oppressed" (p. 227).

We are encouraged that participants sometimes challenged such disconfirmation by insisting on detailed feedback and explanations of why their work was considered wrong. Yet in other instances, such as when Sally chose not to challenge her advisor's suggested revisions, the participants were more submissive. In both instances, they were enacting human agency in an effort to negotiate their success as writers in a new language and culture.

As educators, we should take note of this effort. Albertinti (2010) suggests that it is not enough to "simply acknowledge, respect, or celebrate differences among our students. We must understand how these differences affect student learning, our teaching, and our scholarship" (p. 388). Until this understanding becomes reality, researchers must continue to make spaces for international students to share their experiences in U.S. classrooms, while at the same time looking within, at how our own practices impact international students.

This study was interpretive and context specific, therefore findings are not intended to be generalized. The study also was limited to female participants, and only interviews and writing samples were used as data. Future studies could include male participants and observation of student interactions with professors or tutors.

\section{Implications}

University policymakers must move beyond the obvious to seek new ways of addressing the growing challenges of educating international students. Certainly TOEFL scores or existing ESL programs may need to be re-examined, with assurances that programs are staffed with certified second-language teachers and that training includes instruction in the types of writing that students will be assigned at the university. Within the university, writing courses designed for second-language learners are needed, focusing on discipline-specific college writing. And writing centers must move beyond student workers and hire professional tutors familiar with international students' challenges and with the academic writing styles they will be required to use. But we believe both university policymakers and faculty must look within and question assumptions and practices that continue to discount or fail to recognize international students' knowledge and ways of knowing. A good place to start would be to make spaces where administration and faculty sit down with international students to discuss not just old problems but new possibilities for the academic experiences of second-language learners.

\section{REFERENCES}

Abasi, A. R., \& Graves, B. (2008). Academic literacy and plagiarism: Conversations with international graduate students and disciplinary professors. Journal of English for Academic Purposes, 7(4), 221-233. doi:10.1016/j.jeap.2008.10.010 
Albertinti, J. (2010). Teaching of writing and diversity: Access, identity, and achievement. In C. Bazerman (Ed.), Handbook of research on writing: History, society, school, individual, text (pp. 387-397). New York, NY: Routledge.

Alsahafi, N., \& Shin, S. (2017). Factors affecting the academic and cultural adjustment of Saudi international students in Australian universities. Journal of International Students, 7(1), 53-72. Retrieved from https://jistudents.org/2017vol71/

Angelova, M. \& Riazantseva, A. (1999). "If you don't tell me, how can I know?" A case study of four international students learning to write the U.S. way. Written Communication, 16(4), 491-525. Retrieved from http://wcx.sagepub.com/

Ankawi, A. (2015). The academic writing challenges faced by Saudi students studying in New Zealand (Master's thesis). Retrieved from https://aut.researchgateway.ac.nz/ bitstream/handle/10292/9187/AnkawiA.pdf?sequence=3\&isAllowed=y

Baird, C., \& Dooey, P. (2014). Ensuring effective student support in higher education alleged plagiarism cases. Innovative Higher Education, 39, 387-400. doi:10.1007/s10755-014-9285-4

Bauer, H., \& Picciotto, M. (2013). Writing in America: International students and first-year composition. Writing on the Edge, 23(2), 75-86. Retrieved from http://woe.ucdavis.edu/

Bitchener, J., Young, S., \& Cameron, D. (2005). The effect of different types of corrective feedback on ESL student writing. Journal of Second Language Writing, 14(3), 191-205. doi:10.1016/j.jslw.2005.08.001

Chandler, J. (2003). The efficacy of various kinds of error feedback for improvement in the accuracy and fluency of L2 student writing. Journal of Second Language Writing, 12(3), 267-296. doi:10.1016/S1060-3743(03)00038-9

Fass-Holmes, B. \& Vaughn, A. A. (2014). Are international students struggling academically? Journal of International Students, 4(1), 60-73. Retrieved from http://jistudents.org/

Giroux, H. A. (1983). Theory and resistance in education: A pedagogy for the opposition. South Hadley, MA: Bergin \& Garvey Publishers.

Glesne, C. (2006). Becoming qualitative researchers (3 ed.): An introduction. Boston, MA: Pearson Education.

Institute of International Education. (2017). Open Doors 2017 executive summary. Retrieved from https://www.iie.org/Why-IIE/Announcements/2017-11-13-Open-Doors-2017-ExecutiveSummary

Kuo, Y-H. (2011). Language challenges faced by international graduate students in the United States. Journal of International Students, 1(2), 38-42. https://jistudents.files.wordpress.com/2011/06/4language-challenges-faced-by-international-students.pdf

LeCompte, M. D., \& Schensul, J. J. (1999). Analyzing \& interpreting ethnographic data. Walnut Creek, CA: Altamira Press.

Leki, I. (1995). Coping strategies of ESL students in writing tasks across the curriculum. TESOL Quarterly, 29(2), 235-260. Retrieved from http://www.tesol.org/read-and-publish/journals/tesol-quarterly

Leki, I., \& Carson, J. (1994). Students' perceptions of EAP writing instruction and writing needs across the disciplines. TESOL Quarterly, 28(1), 81-101. Retrieved from http://www.tesol.org/read-andpublish/journals/tesol-quarterly

Leki, I., \& Carson, J. (1997). "Completely different worlds": EAP and the writing experience of ESL students in university courses. TESOL Quarterly, 31(1), 39-68. Retrieved from http://www.tesol.org/read-and-publish/journals/tesol-quarterly

Leng, K. T. (2014). An analysis of written feedback on ESL students' writing. Procedia - Social and Behavioral Sciences, 123, 389-397. doi:10.1016/j.sbspro.2014.01.1437

Lewin, T. (2012, February 4). Taking more seats on campus, foreigners also pay the freight. The New York Times. Retrieved from http://www.nytimes.com/pages/education/index.html

Moussu, L. (2013). Let's talk! ESL students' needs and writing center philosophy. TESL Canada Journal, 30(2), 55-68. Retrieved from http://www.teslcanadajournal.ca/index.php/tesl/index 
Ravichandran, S., Kretovics, M., Kirby, K., \& Ghosh, A. (2017). Strategies to address English language writing challenges faced by international graduate students in the US. Journal of International Students, 7(3), 764-785. doi:10.5281/zenodo.570033

Riazantseva, A. (2012). "I ain't changing anything": A case study of successful generation 1.5 immigrant college students' writing. Journal of English for Academic Purposes. 11(3). 184-193. doi:10.1016/j.jeap.2012.04.007

Seror, J. (2009). Institutional forces and L2 writing feedback in higher education. The Canadian Modern Language Review, 66(2), 203-232. doi:10.3138/cmlr.66.2.203

Shang-Butler, H. (2015). Great expectations: A qualitative study of how Chinese graduate students navigate academic writing expectations in U.S. higher education (Doctoral dissertation). Available from ProQuest Dissertations \& Theses Global. (UMI No. 1688715216)

Singh, M. (2015). International graduate students' academic writing practices in Malaysia: Challenges and solutions. Journal of International Students. 5(1). 12-22. Retrieved from https://jistudents.org/

Spack, R. (1997). The acquisition of academic literacy in a second language: A longitudinal case study. Written Communication, 14(1), 3-37. Retrieved from http://wcx.sagepub.com/

Trice, A. G. (2003). Faculty perceptions of graduate international students: The benefits and challenges. Journal of Studies in International Education, 7(4), 379-403. doi:10.1177/1028315303257120

Wan, G. (1999). The learning experiences of Chinese students in American universities: A cross-cultural perspective. Retrieved from http://files.eric.ed.gov/fulltext/ED439653.pdf

Wang, L. (2012). Behind the curtain: A critical view of theory and practice of tutoring international English language learners at university writing centers (Doctoral dissertation). Available from ProQuest Dissertations \& Theses Global. (UMI No. 1012118289)

Wang, T., \& Li, L. Y. (2008). Understanding international postgraduate research students' challenges and pedagogical needs in thesis writing. International Journal of Pedagogies and Learning, 4(3), 8896. doi:10.5172/ijpl.4.3.88

Weaver, R., \& Jackson, D. (2011). Evaluating an academic writing program for nursing students who have English as a second language. Contemporary Nurse, 38(1-2), 130-138. doi:10.5172/conu.2011.38.1-2.130

Whitley, E., \& Grous, A. (2009). Academic writing by 'international' students in the Internet age: studying diversity in practice. International Journal of Innovation in Education. 1(1), 12-34. Retrieved from http://www.inderscience.com/jhome.php?jcode=ijiie

Zghyer, R. (2014). Arab students' difficulties with English writing during their transition to the United States: An exploratory study (Doctoral dissertation). Available from ProQuest Dissertations and Theses. (UMI No. 3640931)

ABIR ALY ELDABA, PhD, is an internal evaluator for the Oakley STEM Center at Tennessee Technological University and an ESL instructor. Her research interests include international students, literacy, and multicultural education. Email: aeldaba@tntech.edu

JANET KESTERSON ISBELL, PhD, is an associate professor at Tennessee Technological University and the president of the Tennessee chapter of the National Association for Multicultural Education. Her research interests include international students, poverty, literacy, and rural education. Email: jisbell@tntech.edu 